\title{
Effects of Invertebrates in Lotic Ecosystem Processes
}

\author{
J.B. Wallace ${ }^{1,2}$ and J.J. Hutchens, Jr ${ }^{1}$ \\ ${ }^{1}$ Institute of Ecology and ${ }^{2}$ Department of Entomology, \\ University of Georgia, Athens, GA 30602, USA
}

\section{Introduction}

Freshwater invertebrates perform many roles in ecosystem processes (Palmer $e t$ al., 1997) and these roles are frequently associated with a diverse array of feeding habits which have been organized into functional feeding groups (FFGs). Wallace and Webster (1996) reviewed many roles of FFGs in stream ecosystems. Streams differ markedly from most ecosystems in that the unidirectional flow of water through areas of different relief, lithology, runoff and large woody debris generates an array of channel forms (Brussock et al., 1985). These various channel forms result in many diverse habitats (Frissell et al., 1986), which place many constraints on organisms and the type and form of their food resources. This physical heterogeneity, including substrate and current velocity, is important in that it influences many aspects of stream ecology including nutrient dynamics, biotic diversity of animals, functional feeding groups, predator-prey interactions, refugia from disturbances, micro- and macroflora, organic matter retention and transport, as well as local secondary production (see Wallace and Webster, 1996).

Most streams have a highly diverse macroinvertebrate assemblage which is represented by several FFGs that have evolved a diverse array of morphobehavioural mechanisms for exploiting foods. Throughout this chapter we will follow the functional classification of Merritt and Cummins (1996), which is based on mechanisms used by invertebrates to acquire foods. These functional groups are as follows: scrapers, animals adapted to graze or scrape materials from mineral and organic substrates; shredders, organisms that comminute primarily coarse particulate organic matter (CPOM $\geqslant 1 \mathrm{~mm}$ diameter); gatherers, animals that feed primarily on fine particulate organic matter (FPOM $\leqslant 1 \mathrm{~mm}$ (C) CAB International.2000. Invertebrates as Webmasters in Ecosystems (eds D.C. Coleman and P.F. Hendrix) 
diameter) deposited within streams; filterers, animals that have specialized anatomical structures (e.g. setae, mouthbrushes or fans, etc.) or silk and silklike secretions that act as sieves to remove particulate matter from suspension (Wallace and Merritt, 1980); and predators, those organisms that feed primarily on animal tissue.

These FFGs refer primarily to modes of feeding or the food acquisition system (sensu Cummins, 1986) and not type of food per se. For example, many filter-feeding insects in streams are primarily carnivores (e.g. Benke and Wallace, 1980, 1997). Scrapers also consume quantities of what must be characterized as epilithon (FPOM, accompanying microbiota, algae) and not solely attached algae. Likewise, although shredders may select materials that have been 'microbially conditioned' by colonizing fungi and bacteria (e.g. Cummins and Klug, 1979), these shredders also ingest attached algal cells, protozoans and various other components of the fauna during feeding (Merritt and Cummins, 1996). While it appears valid to separate taxa according to the mechanisms used to obtain foods, many questions remain concerning the ultimate sources of assimilated energy for each of these functional groups (e.g. Mihuc, 1997).

In most streams draining forested regions in eastern North America, allochthonous inputs from the surrounding forest far exceed inputs from withinstream primary production (Webster et al., 1995). Only tundra and arid land streams appear to have levels of autochthonous production exceeding those of allochthonous inputs (Webster and Meyer, 1997). Thus, it is not surprising that animal assemblages of streams draining forested regions have long been viewed as relying primarily on allochthonous inputs from the surrounding forest (Cummins, 1973). Most of the particulate organic matter entering streams draining forested regions is primarily in the form of CPOM, leaves and woody debris (Fig. 4.1), which usually compose a large portion of the total particulate organic matter (POM) standing crop (Jones, 1997). In the absence of storms, very little of the organic matter stored in headwater streams is exported as CPOM. Most carbon loss at baseflow is in the form of FPOM and dissolved organic carbon (DOC) (Naiman and Sedell, 1979; Webster and Patten, 1979; Wallace $e t$ al., 1982). Thus, shallow headwater streams can be thought of as sites of input, storage, transformation and export of organic matter, since DOC and FPOM are much more amenable to entrainment and downstream transport compared with CPOM. Although DOC does enter the stream through groundwater, some of this $\mathrm{DOC}$ is derived from leaf litter stored within the wetted channel (Meyer et al., 1998). Invertebrates promote downstream transport by bioturbation and conversion of CPOM to more easily transported FPOM (Fig. 4.1). Downstream organisms, especially filterers, promote retention of organic matter, whereas other functional groups such as grazers, gatherers and predators often enhance transport through their feeding activities. In larger downstream areas, most organic matter is available as either suspended or deposited FPOM, and these regions are dominated by filterers, gatherers, predators and, to a lesser extent, shredder-herbivores when macrophytes are available (Fig. 4.1). 
Headwaters

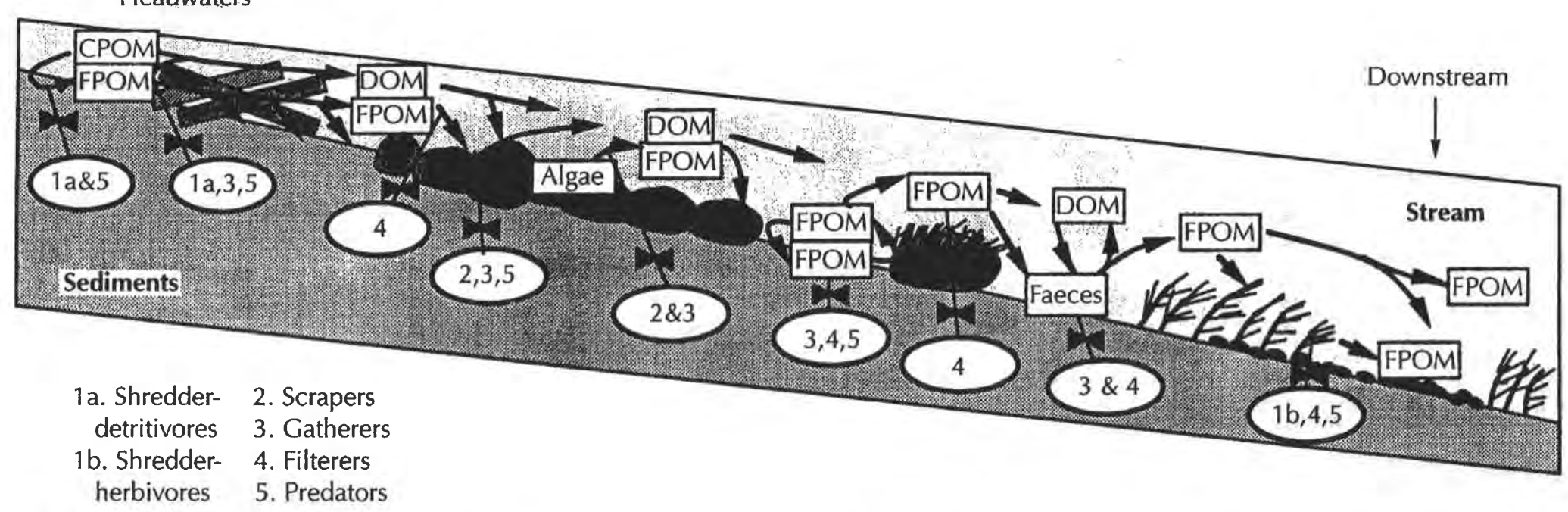

Fig. 4.1. A conceptual diagram showing how invertebrate functional feeding groups affect different ecosystem processes along a hypothetical stream gradient. Note how different reaches along the gradient are dominated by different resources and abiotic conditions. Upstream reaches (left) often have much stored CPOM behind woody debris dams. Middle reaches can be active sites of algal production on cobble and boulders, while downstream reaches (right) can have abundant aquatic macrophytes and large inputs of FPOM from upstream. Also, notice how FPOM and DOM are important resources along the entire stream length. Processes affected by functional feeding groups (1-5) are indicated by lines with hourglass symbols and are described in the text. 
This chapter focuses on various processes that are influenced by invertebrate activities rather than on individual functional groups themselves. Invertebrates influence lotic ecosystem processes by several mechanisms, which we will discuss in the following sections. First, invertebrates alter resource quantity, size and shape. Second, invertebrates enhance downstream movement of carbon and associated nutrients. Third, their activity can also enhance retention of carbon and nutrients. Fourth, predators, through their influence on standing crop of prey, may affect all processes. Finally, we address how largescale physical changes along stream gradients affect invertebrate assemblages and their primary roles in stream ecosystems.

\section{Invertebrate Activities that Alter Resource Quantity, Size and Shape}

Invertebrates have been shown to alter organic resources in streams by various mechanisms, including grazing of periphyton assemblages by scrapers (=grazers), feeding on macrophytes, shredding of leaf detritus and processing of woody debris. These activities can affect ecosystem structure by reducing standing crops and modifying assemblage structure of both primary producers and heterotrophs. Ecosystem processes can also be changed, for example primary production.

Since early reviews by Gregory (1983) and Lamberti and Moore (1984) there have been numerous studies of periphyton-scraper interactions. A classic example dramatically demonstrating grazing effects on algae was conducted in a California stream by Lamberti and Resh (1983), where grazing caddisflies greatly reduced the standing crop of algae and increased algal turnover rate. The important role of grazers in many streams was highlighted by a metaanalysis of 89 stream experiments, which indicated that grazers maintained at ambient densities reduced periphyton biomass $70 \%$ of the time (Feminella and Hawkins, 1995). Furthermore, comparison of periphyton community structure with and without grazers indicated that $>80 \%$ of the experiments showed grazers altered algal taxonomic and physiognomic structure (Feminella and Hawkins, 1995).

Although macrophytes in streams are generally assumed to be rarely fed upon, invertebrate consumption of living macrophytes may be important (see review by Newman, 1991). For example, floating-leaf macrophytes, such as Nuphar, can be heavily grazed and contribute high quality FPOM to the detrital food web throughout the growing season (Wallace and O'Hop, 1985). Some macroinvertebrates have been used successfully as biological control agents of introduced aquatic macrophytes such as alligatorweed and Hydrilla in Coastal Plain streams (Buckingham, 1994). However, feeding on submerged macrophytes in streams is poorly studied in North America, although some European studies do indicate that grazing can be significant at certain times during the growing season (Jacobsen, 1993; Jacobsen and Sand-Jensen, 1994a, b). 
verteielves. which ource ement hance uence largeblages

arious zzers), voody nding ss and imary

1984) jlassic ted in lisflies $r$ rate. metaned at la and icture towed $a$ and

siy fed it (see ich as etrital Some ints of oastal tacroopean Ig the a, b).

Overall, the impact of aquatic invertebrates on submerged macrophytes and the ecosystem consequences of shredder-herbivores are not well known (Newman, 1991).

Invertebrate shredders in laboratory streams increase the rate of conversion of CPOM to FPOM (Petersen and Cummins, 1974). Shredders generally have low assimilation efficiencies and high ingestion rates (McDiffett, 1970; Golladay et al., 1983), resulting in much FPOM generation (McDiffett, 1970). A direct relationship was also shown between shredder activity, leaf litter breakdown and subsequent ingestion of fine particles by filter-feeding insects (Short and Maslin, 1977). Furthermore, laboratory feeding studies indicate that shredders facilitate leaching of DOC from CPOM (Meyer and O'Hop, 1983).

The importance of invertebrates in processing large detrital particles is not limited to leaf litter, but also includes woody debris. Wood breakdown is much slower in freshwater than in terrestrial ecosystems (Harmon et al., 1986) and is primarily a surface area phenomenon in freshwater habitats (Triska and Cromack, 1980). Invertebrate shredders and scrapers promote wood decomposition by scraping, gouging and tunnelling through wood (Anderson and Sedell, 1979; Dudley and Anderson, 1982), which exposes additional surfaces to microbial colonization and decomposition (Anderson and Sedell, 1979). An astonishing example of how aquatic insects can increase wood breakdown is an incidence of caddisflies causing a bridge to collapse. The collapse was a result of wood gouging by generations of hydropsychids for their retreats on the wooden bridge pilings (NTSB, 1989). In addition, feeding grooves in wood left by elmid beetles can enhance colonization by other invertebrate species (McKie and Cranston, 1998).

\section{Invertebrate Activities that Enhance Movement of Carbon and Nutrients}

Invertebrate assemblages within stream reaches influence the movement or loss of nutrients through their feeding and activity. However, this influence is difficult to estimate because of a number of problems associated with studying fine particle movement. Still, taxa from various FFGs have been found to increase particle export and thus influence the movement of energy in stream ecosystems.

The influence of the entire insect community on particle movement was addressed in studies conducted at the Coweeta Hydrologic Laboratory in western North Carolina. The application of an insecticide to a small headwater stream eliminated $>90 \%$ of the aquatic insect biomass and greatly reduced secondary production (Lugthart and Wallace, 1992). This manipulation significantly reduced breakdown rates of leaf litter without significant change in microbial respiration rates of litter in treatment and reference streams (Cuffney et al., 1990). In the treatment, or macroinvertebrate-reduction stream, 
export of FPOM was greatly reduced compared with that of nearby, untreated reference streams (Wallace et al., 1982, 1991; Cuffney et al., 1990). Following treatment, restoration of invertebrate shredder populations coincided with a return of leaf litter processing rates (Wallace et al., 1986; Chung et al., 1993) and FPOM export (Wallace et al., 1991) similar to pretreatment and reference stream levels. These studies demonstrated that macroinvertebrates accounted for 25-28\% of annual leaf litter processing (Cuffney et al., 1990) and 56\% of FPOM export (Wallace et al., 1991). The 56\% reduction in export during the 3 -year treatment was equivalent to 161-198 kg ash-free dry mass less FPOM export to downstream reaches (Wallace et al., 1991). These studies also indicate that the influence of invertebrate populations is as great on inorganic as on organic matter export (Wallace et al., 1993). Lower whole-stream export of inorganic particles following pesticide treatment was attributed to at least two mechanisms: (i) the rate of particle generation by feeding activities of animals was reduced; (ii) the increased storage of leaf litter enhanced retention of particles.

We still have much to learn about transport processes of fine particles in streams. McNair et al. (1997) identified several major questions including: By what methods do particles become entrained in the water column? What is the length of time required for particles to reach the bottom? How far do particles travel? and What determines whether settled particles are retained or reflected? Although such questions are important to benthic organisms and ecosystem processes, the complications involved with applying the modelling efforts such as those of McNair et al. (1997) to heterogeneous areas of streams, which differ with respect to velocity, depth, substrate and turbulence, would appear to be overwhelming. Nevertheless, various taxa of scrapers, gatherers and filterers have been shown to enhance particle export.

Several studies have shown that grazing snails (Mulholland et al., 1983; Lamberti et al., 1989) and insects (Dudley, 1992) increase downstream export of FPOM from grazed substrates. Heavy grazing results in periphyton mats with closely appressed adnate forms of diatoms which are less susceptible to scouring and loss during disturbances such as large storms (Mulholland et al., 1991). Experimental studies have also shown that grazing promotes nutrient turnover in periphyton communities (Steinman et al., 1995). Hence, grazing may result in a consistent, prolonged release of materials to downstream reaches, in contrast with large storms that induce pulsed massive export over short time intervals. A very similar role was suggested for shredders (Wallace et al., 1982; Cuffney et al., 1984).

The role of gatherers in FPOM transport was implicated by Cushing et al. (1993). These authors found that labelled FPOM released into an Idaho stream exhibited continuous deposition and resuspension as particles moved downstream. This flux of FPOM indicated that gatherers feeding on FPOM may induce regular, diffuse downstream transmission of their food rather than local depletion (Cushing et al., 1993). Other studies have also suggested that invertebrate collectors increase the downstream movement of materials. For 
เtreated llowing 1 with a , 1993) :ference sounted $56 \%$ of ing the s FPOM ies also organic 1 export zast two inimals ition of

ticles in ling: By at is the articles flected? ssystem ts such sh differ ar to be filterers

, 1983; 1 export ats with ) scour1991). urnover y result 'hes, in ort time , 1982;

ng et al. stream I downIM may an local ed that als. For example, in montane Puerto Rican streams, feeding activities of atyid shrimp reduce organic matter accrual on benthic substrates (Pringle et al., 1993). Other invertebrate gatherers transfer fine organic matter buried in depositional areas to substratum surfaces as faeces. Larvae of Ptychoptera (Diptera: Ptychopteridae) possess an elongate caudal respiratory tube which allows them to feed on buried organic matter in shallow areas while maintaining contact with atmospheric air. The larvae preferentially feed in substrates that have a high percentage of fine organic matter and high microbial biomass (Wolf et al., 1997). Based on gut passage times, larval life histories and AFDM of faecal pellets, Wolf et al. (1997) suggest that Ptychoptera transfer $770 \mathrm{~g} \mathrm{DW} \mathrm{m}^{-2}$ year $^{-1}$ ( $\approx 123 \mathrm{~g} \mathrm{AFDM}$ ) of buried sediments to the substrate surface as faeces. These faeces are readily available as food to other invertebrates, as well as subsequent transport to downstream areas (Wolf et al., 1997).

Although filter-feeding invertebrates typically decrease losses of organic matter and nutrients within a given stream segment (Wallace and Webster, 1996), some may also increase losses. Ametropus spp. mayflies are unusual among filterers in that they occupy unstable, sandy-bottom areas of large rivers. Ametropus uses the head, mouthparts and forelegs to create a shallow pit, which initiates a unique vortex in front of the head and results in resuspension of fine organic matter as well as occasional sand grains. Some of the resuspended particles are then apparently captured by setae on the mouthparts and forelegs. Hence, Ametropus exploit the abundant fine organic particles entrapped in the sediments of large sandy-bottom rivers, but also increase their movement downstream (Soluk and Craig, 1988).

\section{Invertebrate Activities that Enhance Retention}

Retention of organic matter and nutrients is affected primarily by filter-feeding stream invertebrates; however, other functional groups may also be important. For example, cycling of nutrients in food webs can immobilize nutrients in stream reaches. Also, burrowing activity by invertebrates can transport surface organic matter to deeper sediments, which reduces downstream transport. In addition, structures created by some insects can serve as sites of travertine $\left(\mathrm{CaCO}_{3}\right)$ deposition. Nevertheless, direct removal of transported material by filter-feeders has received the bulk of attention and has been shown to have variable effects on retention depending on size of stream, abundance of filterers and taxa-specific differences in feeding.

The transformation and storage of nutrients by invertebrates can have a: significant influence on nutrient export and overall efficiency of nutrient retention within streams (Merritt et al., 1984), but quantifying the role of invertebrates in nutrient cycling in streams has received little study. A 6-week nutrient tracer addition $\left(\left[{ }^{15} \mathrm{~N}\right] \mathrm{NH}_{4}\right)$ to a small tundra river in Alaska during the summer resulted in rapid labelling of primary producers (filamentous algae, epilithon and moss), which was then quickly incorporated into invertebrate 
scrapers, for example Baetis and chironomid larvae (Peterson et al., 1997). Among filtering invertebrates, such as Prosimulium, the peak in label within larvae occurred further downstream than in scrapers, suggesting that these downstream filterers were relying on FPOM produced by sloughing of epilithon (Peterson et al., 1997). Presumably scraper activity, including egested faeces, also contributed to the downstream increase in label found in simuliids. Those aquatic insects with long-lived larval stages ( $>1$ year, i.e. the caddisflies Brachycentrus and Rhyacophila) retained the labelled nitrogen for at least 2 years following termination of the ${ }^{15} \mathrm{~N}$ release. In fact, 1 year following the treatment these caddisflies retained a higher proportion of labelled nitrogen than the epilithon (Peterson et al., 1997). It should be noted that even those animals with shorter life histories (e.g. chironomids and simuliids) emerge and transport nutrients back to the terrestrial environment, which also reduces losses of nutrients from the catchment.

Some burrowing animals increase transfer of organic matter from the stream bed surface to deeper sediments, thereby making the organic matter less amenable to downstream transport, and enhancing retention. Larvae of the European sericostomatid caddisfly, Sericostoma personatum, feed on surface CPOM at night and burrow into the stream bed during the day. Subsequent defecation by $S$. personatum increased subsurface sediment organic content by 75-185\% compared with controls containing no sericostomatid larvae in the laboratory (Wagner, 1991). A somewhat similar phenomenon may occur with other sericostomatid larvae such as the western North American species, Gumaga nigricula, which transfers case-associated algae into the sediments by abrasion during burrowing (Bergey and Resh, 1994).

Although filter-feeding hydropsychid caddisflies primarily retain organic matter through their filtering (see below), their retreats and silken nets can also act as important substrates for calcium carbonate precipitation in travertine streams (Drysdale, 1999). Drysdale found that Cheumatopsyche larvae in a small, spring-fed stream in Australia enhanced rates of travertine deposition in three ways. First, the retreat and net act as sites for $\mathrm{CaCO}_{3}$ precipitation, and become completely encrusted over time. Second, the encrusted retreats and nets that are incorporated into the travertine increase rock porosity, and increase the accumulation rate. Third, the retreats and nets increase bed surface roughness, which disrupts flow and enhances turbulence, thereby enhancing rates of $\mathrm{CO}_{2}$ outgassing and $\mathrm{CaCO}_{3}$ precipitation. Overall, these hydropsychid structures enhanced travertine deposition from about twofold in areas where background rates of precipitation were high, to about 20 -fold where background rates were low (Drysdale, 1999).

Streams transport large amounts of organic matter, primarily in the form of DOM and FPOM. Most seston carried by streams consists of particles $<50 \mu \mathrm{m}$ in diameter, and many groups including some ephemeropterans, trichopterans (Philopotamidae) and dipterans (Simuliidae and some Chironomidae) have evolved mechanisms to feed on these minute particles (Wallace and Merritt, 1980). Bivalves consume even smaller particles on average, generally ranging 
, 1997).

I within at these spilithon 1 faeces, s. Those Idisflies $t 2$ years eatment han the lals with ansport osses of

rom the itter less le of the surface sequent atent by te in the sur with species, lents by

organic zan also ivertine vae in a sition in on, and ind nets ease the ghness, $\mathrm{s}$ of $\mathrm{CO}_{2}$ uctures ground es were

he form : $50 \mu \mathrm{m}$ pterans e) have verritt, anging from $\leqslant 1$ to $10 \mu \mathrm{m}$ (Thorp and Covich, 1991). Microfilterers, such as the Philopotamidae, Simuliidae and bivalves, increase particle sizes by ingesting minute particles and egesting compacted faecal particles larger than those originally consumed. Such microfilterers perform two very important functions in streams. First, they remove fine particulate organic matter from suspension (which would otherwise pass unused through the stream segment) and second, they defecate larger particles, which are available to deposit-feeding detritivores (Wallace and Webster, 1996). Filterers were hypothesized to reduce downstream transport of suspended POM (Wallace et al., 1977) and decrease spiralling distances of nutrients and organic matter (Webster and Patten, 1979; Newbold et al., 1982).

Most studies of seston removal by filterers have suggested low rates of seston removal, i.e. generally well below $1 \%$ seston removal per $\mathrm{m}$ length of stream (Georgian and Thorp, 1992). The highest rates of seston removal by insect filter-feeders in streams have been obtained in studies that incorporated microfilterers such as Simuliidae. Morin et al. (1988) found that simuliid larvae ingested $0.8-1.4 \%$ of the seston per $m$ of stream below a Quebec lake outlet; these are the highest rates of seston removal reported. The study of Morin et al. was made during low flows in late spring when the standing stock of black flies was high, whereas other studies, performed on an annual basis, indicated lower rates of seston removal. However, even low rates of seston removal can have a surprising impact on removal of FPOM from the water column. Recently, Wotton et al. (1998) studied a short length of a small Swedish stream which drained directly into the Baltic Sea, and found that $33 \%$ of the faecal pellets produced by black fly larvae were sedimented or intercepted before reaching the Baltic. Wotton et al. (1998) found that filter-feeder removal of seston was only $0.06 \%$ per $m$ linear stream length. Despite this low rate of removal, Wotton et al. (1998) estimated that black fly faeces added $87 \mathrm{~g} \mathrm{C} \mathrm{m}^{-2}$ year -1 to the stream bottom using a conservative estimate of black fly larvae being in the stream for only 1 month. These faecal particles are thus available to a number of depositfeeding collectors (Wotton et al., 1998). Hall et al. (1996) used fluorescently labelled bacteria (FLB) and found much lower rates of removal than those reported by either Morin et al. (1988) or Wotton et al. (1998). In the headwater stream studied by Hall et al. (1996) only $7 \%$ of the FLB removal was by filterfeeding insects, with simuliid larvae accounting for most of the $7 \%$ removed. Instead, most FLB were removed by sedimentation. However, densities of black flies in the study of Wotton et al. (1998) were 52-125 times higher than those studied by Hall et al. (1996), which probably explains the differences in removal rates.

Rates of seston removal by filtering insects are much lower for large rivers than the above estimates for small streams (Benke and Parsons, 1990; Benke and Wallace, 1997; but see below for molluscs). In the Ogeechee River, Georgia, caddisflies removed only $\approx 0.0001 \%$ of seston per linear $\mathrm{m}$ of stream length; however; their removal of animal drift was about 190 times greater than seston particles such that the caddisflies were capable of removing all drifting animals 
in about $5 \mathrm{~km}$ (Benke and Wallace, 1997). Indeed, many filter-feeding macroinvertebrates consume a wide array of food types. Larger particle-feeding hydropsychids (Trichoptera) are selective towards higher quality food items such as diatoms and animal drift (Benke and Wallace, 1980, 1997; Petersen, $1985,1989)$. This, and generally low rates of seston removal by hydropsychids, suggests that their major impact is on the quality and type of POM in suspension (Benke and Wallace, 1980, 1997; Petersen, 1989; Georgian and Thorp, 1992). Georgian and Thorp (1992) estimated that two Hydropsyche species in riffles of a small New York stream removed drifting invertebrate prey at a rate of $18 \%$ per $\mathrm{m}$. The experiments by Georgian and Thorp are very relevant to ecologists studying downstream drift of invertebrates because they show that when large net-spinning caddisfly populations are present in shallow streams, Hydropsyche predation may reduce stream drift.

Bivalve molluscs represent another agent of seston removal by filterfeeding invertebrates. In the Ogeechee River, Georgia, Stites et al. (1995) used secondary production and bioenergetic efficiencies to estimate seston removal by the Asiatic clam, Corbicula fluminea, and found little evidence of significant seston removal. In contrast, $C$. fluminea populations in the Potomac River estuary reached extremely high densities and were estimated to filter about onesixth of the estuary volume each day (Phelps, 1994). The author also attributed an increase in submerged aquatic vegetation to increases in water clarity and light penetration, resulting from removal of phytoplankton by Corbicula (Phelps, 1994).

Invasion of the zebra mussel, Dreissena polymorpha, into the freshwater tidal portion of the lower Hudson River resulted in massive abundance, estimated as $\sim 550$ billion individuals river-wide, and was considered to be the main agent behind a decline in phytoplankton (Caraco et al., 1997). Summer chlorophyll concentrations decreased from $30 \mu \mathrm{g} \mathrm{I}^{-1}$ prior to invasion to $<5 \mu \mathrm{g} \mathrm{l}^{-1}$ after establishment of Dreissena (Caraco et al., 1997). This decline in phytoplankton was followed by a strong decline $(>70 \%)$ in zooplankton populations in the Hudson River, including flagellated protozoans (Pace et al., 1998).

Zebra mussels are not efficient removers of sestonic bacteria, but are very effective removers of flagellated protozoans, which are major predators'of bacteria. The decline in zooplankton, including flagellated protozoans, in the Hudson River resulted in an overall increase in planktonic bacteria (Findlay et al., 1998). Although bacteria abundance increased, production did not, indicating that bacterial growth was limited by carbon supply following the invasion by Dreissena (Findlay et al., 1998). In the River Spree, a lake-outflow stream in Germany, bivalve populations, including Dreissena and unionid mussels, were estimated to filter the entire daily discharge over a 21-km reach of the river (Welker and Walz, 1998). Purthermore, Welker and Walz (1998) observed significant downstream decreases in chlorophyll as well as in zooplankton populations, which were attributed to mussel feeding. Clearly, intense filter-feeding activity by bivalves can produce pronounced effects in food webs and has many indirect effects in rivers. 
; macrofeeding d items etersen, sychids, suspenI Thorp, recies in a rate of :vant to ow that itreams,

y filter15) used :emoval nificant Ic River sut onetributed rity and (Phelps,

ter tidal rated as $\mathrm{n}$ agent rophyll -1 after lankton $s$ in the

ure very itors'of $i$, in the Idlay et lid not, ing the sutflow Inionid n reach (1998) II as in Jlearly, in food

Extremely large standing stocks of filtering insects such as caddisflies and black flies can be found under certain conditions including: limited stable substrate; sufficient current velocity; and high-quality organic seston concentrations (Fremling, 1960; Parker and Voshell, 1983; Voshell, 1985; Wotton. 1987). Invariably, some of the highest levels of secondary production in the world are those of filter feeders in streams. Such high densities and production of filterers, compared with all other functional groups, are possible because filterers are using the kinetic energy of the current to exploit foods produced in other habitats and made available to them by the current (Cudney and Wallace, 1980). As a consequence, less energy is expended in search of food, and extremely high biomass per unit area can be supported (Cudney and Wallace, 1980). Thus, in habitats with high particle transport, filterers exploit the physical environment and increase particle retention.

\section{Diversity of Roles for Predators}

Predators can play numerous diverse roles at scales ranging from individuals to ecosystems, and invertebrate (and vertebrate) predators in streams are no exception. Predators can influence export and retention of energy and nutrients through their effects on the standing stocks of other functional groups (Fig. 4.2). Other mechanisms include decreasing rates of nutrient cycling by immobilizing nutrients in long-lived predator taxa versus short-lived prey. Besides direct consumption, foraging by invertebrate predators can enhance invertebrate drift and suspended FPOM, which also increases export of nutrients. Although these specific predation effects have been documented, it has often proved difficult to quantify precisely how predators influence stream processes.

Invertebrate predators can enhance retention of organic matter by retarding breakdown rates of leaf litter as well as subsequent generation of FPOM. For example, predaceous plecopterans and caddisflies significantly decreased the rate of leaf litter processing by reducing shredder populations in leaf packs (Oberndorfer et al., 1984). Predator densities used by Oberndorfer et al. were almost 10 times those of background. However, Malmqvist (1993) used more realistic densities of predators and was not able to demonstrate a reduction in shredder densities in the presence of a predatory stonefly, Diura. Still, he did find that less leaf material was processed in cages with predators. In additional laboratory feeding experiments, two of three shredder species produced less FPOM when exposed to predators (Malmqvist, 1993). Finally, the study by Peterson et al. (1997) (see above) indicated that long-lived predator taxa (i.e. Rhyacophila) can retain tracer additions of nitrogen long after short-lived scraper and filterer larvae have left the stream as adults.

Invertebrate predators can also increase the rate of downstream movement of organisms and sediment. Many stream invertebrates exhibit different responses to fish and invertebrate predators, and the local impact of invertebrate 


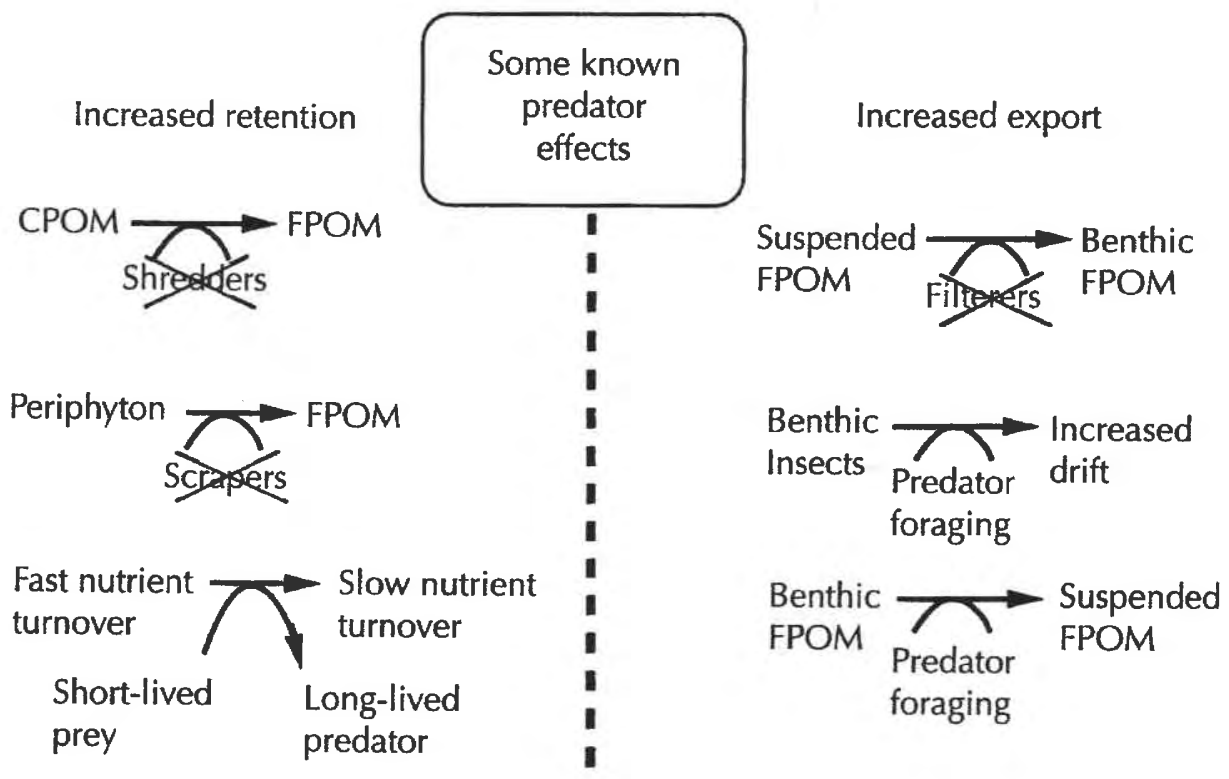

Fig. 4.2. Predators affect many lotic processes by either decreasing (left side of dashed line) or increasing (right side of dashed line) the movement of organic matter and nutrients downstream. These effects result from direct predation on various functional feeding groups or indirectly through their foraging activity. See text for details.

predation on benthic prey may exceed the impact of fish predators (Sih and Wooster, 1994). In the presence of fish, invertebrate prey often reduce movement and seek refuge in the substrate. In contrast, invertebrate predators have the ability to search in sites similar to those being used by their prey and the latter may respond by actively entering the water column and drifting downstream (Sih and Wooster, 1994; Wooster, 1994). Foraging by invertebrate predators can also influence the downstream movement of inorganic material through their physical activities. For example, foraging by a European stonefly, Dinocras sp., was suggested to have an erosion potential of about $200-400 \mathrm{~kg}$ sand $\mathrm{m}^{-2}$ year $^{-1}$ at natural population densities and under favourable flow conditions (Statzner et al., 1996). In addition, hungry stonefly predators tend to remove more fine sediment than fed stoneflies apparently because hungry predators forage more intensively in the interstitial spaces, thereby dislodging fine sediments (Zanetell and Peckarsky, 1996). The unusual predaceous mayfly, Pseudiron sp., feeds primarily on chironomid larvae inhabiting sandy substrates of large rivers. Pseudiron digs pits, which are enlarged by vortex currents around their head, promoting both exposure of chironomid prey and accelerating downstream movement of particles (Soluk and Craig, 1990).

Predators can also cause an increase in primary producers through a reduction in dominant primary consumers. This was well documented by 
Kohler and Wiley (1997), who showed that periphyton biomass increased in several Michigan streams after the collapse of a dominant scraping caddisfly, Glossosoma. This collapse was caused by a parasite, a sub-category of predators, which only affected Glossosoma.

The results of Kohler and Wiley (1997) may also provide insight into why the overall impact of predators is difficult to detect at the community level. The microsporidian parasite acts on a specific taxon, whereas most invertebrate predators consume multiple prey taxa (Allan, 1983; Hall et al., 1996). In fact, many invertebrate predators feed on prey at multiple trophic levels, including other predators (i.e. intraguild predation sensu Polis and Holt, 1992), which complicates conventional food chain theory (Polis, 1994; Hall et al., 1996; Polis and Strong, 1996). Intraguild predation of other invertebrate predators accounts for $16-27 \%$ of all predator ingestion in a small mountain stream at Coweeta; hence, this predation is diffusely distributed among multiple taxa (Hall et al., 1996).

Diffuse predation may be an important reason why the effects of predators are often difficult to show at larger scales in many streams (however, see Power, 1990; Huryn, 1998). In his review of stream food webs, Hildrew (1992) stated the problem with predators as: 'the inference is that either predation is really dynamically trivial in running waters or the experiments are unable to detect the effects through some details of scale, timing, or design'. There is certainly evidence that predators do consume a large quantity of available prey. During a 4-year litter exclusion study for an entire stream at Coweeta, total secondary production in the dominant mixed-substrate habitats declined to $22 \%$ of pretreatment values by the 4 th year, the lowest secondary production reported for streams worldwide (Benke, 1993). Litter exclusion clearly showed strong bottom-up effects extending from primary consumers to predators (Wallace et al., 1997, 1999). Production by predators in the treatment stream was also strongly related to that of their prey. Based on simple bioenergetic efficiencies, the results suggest that production by predators is constrained by productivity of their prey. Thus, despite obvious bottom-up control of productivity in this system, the importance of predators (top-down) cannot be ignored as predators consume most of the benthic invertebrate production (Wallace et al., 1997, 1999). Indeed, detecting such diffuse predation in this detritus-based stream would probably be impossible without multi-year studies that assessed secondary production while simultaneously curtailing the detritus food base.

Some stream studies, which have fish as top predators, have shown strong top-down effects on primary production. Such 'trophic cascades' result when feeding activities of a population at one trophic level have quantitative effects on material and energy flow through non-adjacent trophic levels (Carpenter et al., 1985; Power, 1992a; Huryn, 1998). To our knowledge such trophic cascades are most pronounced in streams (or portions thereof) that have simple food chains where autochthonous production is the primary energy resource and fish are top predators. In most cases, effects were seen only in some species or for certain substrates for a short time (Power, 1990, 1992b); however, 
at least one study (Huryn, 1998) provides compelling evidence for strong topdown effects for an entire year. The introduction of brown trout into a New Zealand stream apparently produced sufficient top-down effects on herbivorous invertebrates to influence standing crop and increase productivity and biomass of periphyton. In contrast, in a nearby stream, the impact of native galaxias fish on herbivorous invertebrates resulted in much less pressure on herbivore species, lower periphyton biomass and productivity (Huryn, 1998). Although fish are the top consumers in these systems, we should not forget that it is through the invertebrates that the effects are propagated either up or down in food webs (Hunter and Price, 1992; Wallace and Webster, 1996).

\section{Large-scale Physical Heterogeneity and Invertebrate Assemblages}

In addition to local physical heterogeneity, there are other large-scale physical changes along stream gradients. These large-scale changes were incorporated into a general framework of stream ecosystems as the river continuum concept (RCC) (Vannote et al., 1980; Minshall et al., 1983). However, results from many areas around the world indicate that changes in energy inputs and biological communities proposed in the RCC are not applicable to all river systems (e.g. Statzner and Higler, 1985; Meyer, 1990; Cushing et al., 1995). In the southern Appalachian Mountains, many biological attributes of streams roughly correspond to those proposed in the original RCC, although some exceptions exist (Grubaugh et al., 1997). Striking differences in functional group production occur at opposite extremes of the Coweeta-Little Tennessee River continuum (Grubaugh et al., 1997). For example, in the headwater stream, shredders, gatherers and predators dominate the invertebrate assemblage, whereas in the larger Little Tennessee River, $80 \%$ of the secondary production is attributable to filter-feeding taxa (Table 4.1). The most remarkable difference between sites is that the production at the river site exceeds that of the shaded, headwater stream by 20 -fold.

In part, the high production at the larger Little Tennessee River site is enhanced by the presence of the aquatic macrophyte, Podostemum ceratophyllum (Michaux). Podostemum probably plays several vital roles in accounting for the high production of invertebrates, including: adding a three-dimensional structure to the substrate and providing additional habitat for invertebrates (Grubaugh et al., 1997); retaining organic matter within the dense macrophyte mat and providing food to non-filtering organisms; adding surface area for colonization by epiphytic diatoms and enhancing algal availability to benthic organisms; providing refugia from foraging predators; and affording protection for invertebrates from physical disturbance such as storm flows, because Podostemum is usually associated with large stable substrate. Hence, it is not surprising that in eastern North America, some of the highest levels of invertebrate production in streams, especially for filterers, are associated with 
ong top0 a New jivorous biomass xias fish arbivore Ithough hat it is lown in

Table 4.1. Habitat-weighted functional group secondary production of benthic invertebrates from two locations along the Little Tennessee River-Coweeta continuum. Catchment 53 (C 53) is a 1st order stream (Wallace et al., 1997) and the Little Tennessee River is a 7 th order river (Grubaugh et al., 1997).

\begin{tabular}{lccrrr}
\hline & \multicolumn{2}{c}{$\begin{array}{c}\text { Production } \\
\text { (g AFDM m }\end{array}$} & & \multicolumn{2}{c}{$\begin{array}{c}\text { Percentage of } \\
\text { total production }\end{array}$} \\
\cline { 2 - 3 } \cline { 5 - 6 } $\begin{array}{l}\text { Functional } \\
\text { feeding group }\end{array}$ & C 53 & $\begin{array}{c}\text { Little } \\
\text { Tennessee River }\end{array}$ & & C 53 & $\begin{array}{c}\text { Little } \\
\text { Tennessee River }\end{array}$ \\
\hline Scrapers & $<0.1$ & 6.7 & & 0.3 & 4.3 \\
Shredders & 2.8 & 5.3 & & 36.4 & 3.4 \\
Gatherers & 2.1 & 12.8 & & 26.9 & 8.3 \\
Filterers & 0.4 & 122.9 & & 5.5 & 80.0 \\
Predators & 2.4 & 6.2 & & 30.9 & 4.0 \\
Total & 7.7 & 153.9 & & & \\
\hline
\end{tabular}

Podostemum (Parker and Voshell, 1983; Voshell, 1985; Grubaugh and Wallace, 1995; Grubaugh et al., 1997).

The dissimilarities in production and community structure between upstream and downstream sites of the Little Tennessee River continuum are a result of resources being unequally distributed along the river gradient. Hall et al. (2000) and Rosi (1997) used the trophic basis of production method (Benke and Wallace, 1980) to estimate annual food consumption by invertebrates at both locations (Table 4.2). Note that invertebrates in the headwaters consume primarily leaf and amorphous detritus stored in the stream, whereas downstream consumption is dominated by amorphous detritus and animal tissue (Table 4.2). In the headwater stream draining a deciduous forest, there is an abundant supply of stored allochthonous detritus, and benthic organic matter exceeds that of the downstream site by more than eightfold (Table 4.3). In contrast, annual transport of organic matter per linear $m$ of stream of the larger river site exceeds that of the headwater stream by more than 260 -fold. Clearly, there are marked differences in the form of organic matter, that is, stored versus transported, available to the benthos (Table 4.3).

The functional structure of the animal community (Table 4.1) reflects this difference in organic matter supply. The high consumption required to support production at the Little Tennessee River site is a direct result of the dominance of filter-feeding hydropsychid caddisflies, which rely on the transport of organic matter and invertebrates from upstream. Obviously, the extraordinarily high consumption required to support secondary production of the Little Tennessee River could not occur without a massive subsidy of organic material from upstream areas delivered by the flow. For example, animal consumption at the study site is greater than local production (Table 4.2), which can only be sustained by input from upstream. Furthermore, the consumption required to support total secondary production in the Little Tennessee River exceeds that of the benthic organic matter standing crop, unlike at the headwater site (Table 
Table 4.2. Estimated annual consumption of various food types for all macroinvertebrates to account for their secondary production in a 1 st order stream (C 53) and the 7th order Little Tennessee River using the trophic basis of production methods of Benke and Wallace (1980, 1997). Data for C 53 are recalculated from July and December values from Hall et al. (2000) and data for Little Tennessee River from Rosi (1997).

\begin{tabular}{lrrrrr}
\hline & \multicolumn{2}{c}{$\begin{array}{c}\text { Consumption } \\
\text { (g AFDM m }\end{array}$} & & \multicolumn{2}{c}{$\begin{array}{c}\text { Percentage of } \\
\text { total consumption }\end{array}$} \\
\cline { 2 - 3 } \cline { 5 - 6 } $\begin{array}{l}\text { Food type } \\
\text { Consumed }\end{array}$ & C 53 & $\begin{array}{c}\text { Little } \\
\text { Tennessee River }\end{array}$ & & C 53 & $\begin{array}{c}\text { Little } \\
\text { Tennessee River }\end{array}$ \\
\hline Algae & 0.5 & 51.6 & & 0.3 & 4.4 \\
Leaf detritus & 65.7 & 73.7 & & 50.2 & 6.4 \\
Wood detritus & 5.3 & 0.0 & & 4.1 & 0.0 \\
Amorphous detritus & 51.1 & 734.3 & & 39.1 & 63.3 \\
Fungi & 1.0 & 0.0 & & 0.8 & 0.0 \\
Animal tissue & 7.3 & 299.8 & & 5.6 & 25.9 \\
Total & 130.9 & 1159.4 & & & \\
\hline
\end{tabular}

4.3). This is also a consequence of the filterers in the Little Tennessee River being supported by the most available resource, FPOM in transport, which is in relatively short supply in the headwaters (Table 4.3). Although most other FFGs at the downstream site are a minor component of total production, their absolute production still surpasses that of the upstream site.

Table 4.3. Some relationships between consumption required to support macroinvertebrate production (see Table 4.2), benthic organic matter standing crops, and FPOM transport (seston) for a headwater stream (C 53) and the 7th order Little Tennessee River.

\begin{tabular}{|c|c|c|}
\hline Parameter & C 53 & Little Tennessee River \\
\hline $\begin{array}{l}\text { Consumption required for production } \\
\left(\mathrm{kg} \mathrm{AFDM}^{-2} \text { year }^{-1}\right)\end{array}$ & 0.15 & 1.16 \\
\hline $\begin{array}{l}\text { Benthic organic matter standing crop } \\
\left.\qquad(\mathrm{kg} \mathrm{AFDM} \mathrm{m})^{2}\right)\end{array}$ & $>2.65^{a}$ & $<0.32^{\mathrm{b}}$ \\
\hline Annual FPOM transport (kg AFDM m ${ }^{-1}$ year ${ }^{-1}$ ) & $141^{c}$ & $37,000^{\mathrm{d}}$ \\
\hline Organic matter standing crop: consumption & 17.7 & 0.27 \\
\hline Organic matter transport: consumption & 940 & 31,900 \\
\hline
\end{tabular}

a From Wallace et al. (1999); does not include large woody debris.

b From Grubaugh et al. (1997); over $50 \%$ of the $0.32 \mathrm{~kg}$ is an aquatic macrophyte, Podostemum ceratophyllum (Michaux), and not readily available for invertebrate consumption.

c Wallace et al. (unpublished).

${ }^{d}$ Rosi (1997). 
stream sduction d from see River

on

le

:e River

4

4

0

3

0

9

or being ch is in er FFGs 1, their

h order

: River

b

shyte, rate

From the broader perspective of the entire basin, headwater streams tend to be shallow, easily obstructed by woody debris, have low stream power and have physical characteristics favouring retention of organic matter inputs from the surrounding forest. The invertebrate assemblage in these small, fishless streams exploits the physical environment and is dominated by shredders, gatherers and invertebrate predators (Table 4.1). Their feeding activities tend to decrease particle size of organic resources and favour downstream export of FPOM, which is more amenable to transport than Iarger CPOM. By contrast, downstream reaches have much higher discharge, greater stream power and less retention, which promote entrainment of organic matter. Again, the invertebrate assemblage exploits the physical characteristics of the system by a dominance of filterers (Table 4.1), which promote retention of entrained organic matter. Thus, in both the upstream and downstream areas, the invertebrate feeding assemblages have evolved to reflect the physical characteristics of the system.

\section{Conclusions}

Many of the processes that we have identified in this chapter occur at scales much smaller, i.e. within patches of substratum, than that of a stream reach. However, while small patches have received some attention among stream ecologists (Minshall, 1988; Pringle et al., 1988), the more difficult problem is assessing how various patches contribute to a given stream reach (Minshall, 1988). Even within small headwater streams of the Little Tennessee River basin, localized habitats, for example moss-covered bedrock, can have an invertebrate assemblage more characteristic of larger downstream reaches (Huryn and Wallace, 1987). Furthermore, within a reach, the relative frequency of different patch types influences invertebrate assemblage structure and hence ecosystem processes within the reach. Over an entire stream continuum, there are thousands of individual patches, whose functions may vary depending on local physical attributes, for example retention or entrainment. There is also the difficult question of how materials are transferred between successive longitudinal patches (e.g. McNair et al., 1997). Obviously, the size and contribution of patches with their respective invertebrate assemblages will need to be incorporated into whole-stream studies, if we are to begin to assess the contribution of benthos to processes at the ecosystem level.

These considerations raise the following questions. What spatial and temporal changes occur within and among patches? What is the relative contribution of major patches to secondary production and biotic processes within a reach? What influences the effectiveness of a patch in assemblage function and in its role in ecosystem processes? Finally, there is the broader question: How do regional differences in slope, geology, watershed area, as well as other abiotic factors, and anthropogenic activities influence patch formation and function? Clearly, it is one thing to show that individual taxa or functional. 
groups of organisms may affect particular processes in streams; however, extrapolating these processes to entire streams will be challenging.

\section{References}

Allan, J.D. (1983) Predator-prey relationships in streams. In: Barnes, J.R. and Minshall, G.W. (eds) Stream Ecology: Application and Testing of General Ecological Theory. Plenum, New York, pp. 191-229.

Anderson, N.H. and Sedell, J.R. (1979) Detritus processing by macroinvertebrates in stream ecosystems. Annual Review of Entomology 24, 351-377.

Benke, A.C. (1993) Concepts and patterns of invertebrate production in running waters. Verhandlungen der Internationalen Vereinigung für Theoretische und Angewandte Limnologie 25, 15-38.

Benke, A.C. and Parsons, K.A. (1990) Modelling black fly production dynamics in blackwater streams. Freshwater Biology 24, 167-180.

Benke, A.C. and Wallace, J.B. (1980) Trophic basis of production among net-spinning caddisflies in a southern Appalachian stream. Ecology 61, 108-118.

Benke, A.C. and Wallace, J.B. (1997) Trophic basis of production among riverine caddisflies: implications for food web analysis. Ecology 78, 1132-1145.

Bergey, E.A. and Resh, V.H. (1994) Effects of burrowing by a stream caddisfly on caseassociated algae. Journal of the North American Benthological Society 13, 379-390.

Brussock, P.P., Brown, A.V. and Dixon, J.C. (1985) Channel form and stream ecosystem models. Water Resources Bulletin 21, 859-866.

Buckingham, G.R. (1994) Biological control of weeds by insects. Journal of the Georgia Entomological Society (2nd Suppl.) 19, 62-78.

Caraco, N.F., Cole, J.J., Raymond, P.A., Strayer, D.L., Pace, M.L., Findlay, S.E.G. and Fischer, D.T. (1997) Zebra mussel invasion in a large, turbid river: phytoplankton response to increased grazing. Ecology 78, 588-602.

Carpenter, S.R., Kitchell, J.F. and Hodgson, J.R. (1985) Cascading trophic interactions and lake productivity. BioScience 35, 634-639.

Chung, K., Wallace, J.B. and Grubaugh, J.W. (1993) The impact of insecticide treatment on abundance, biomass, and production of litterbag fauna in a headwater stream: a study of pretreatment, treatment, and recovery. Limnologica 28, 93-106.

Cudney, M.D. and Wallace, J.B. (1980) Life cycles, microdistribution and production dynamics of six species of net-spinning caddisflies in a large southeastern (U.S.A.) river. Holarctic Ecology 3, 169-182.

Cuffney, T.F., Wallace, J.B. and Webster, J.R. (1984) Pesticide manipulation of a headwater stream ecosystem: significance for ecosystem processes. Freshwater Invertebrate Biology 3, 153-171.

Cuffney, T.F., Wallace, J.B. and Lugthart, G.J. (1990) Experimental evidence quantifying the role of benthic invertebrates in organic matter dynamics of headwater streams. Freshwater Biology 23, 281-299.

Cummins, K.W. (1973) Trophic relations of aquatic insects. Annual Review of Entomology 18, 183-206.

Cummins, K.W. (1986) The functional role of black flies in stream ecosystems. In: Kim, K.C. and Merritt, R.W. (eds) Black Flies: Ecology, Population Management, and Annotated World List. Pennsylvania State University Press, University Park, pp. 1-10. 
iwever,

Cummins, K.W. and Klug, M.J. (1979) Feeding ecology of stream invertebrates. Annual Review of Ecology and Systematics 10, 147-172.

Cushing, C.E., Minshall, G.W. and Newbold, J.D. (1993) Transport dynamics of fine particulate organic matter in two Idaho streams. Limnology and Oceanography 38 , 1101-1115.

Cushing, C.E., Cummins, K.W. and Minshall, G.W. (eds) (1995) River and Stream Ecosystems. Ecosystems of the World, Vol. 22. Elsevier, Amsterdam.

inshall,

Theory.

rates in

waters.

wandte

nics in

rinning

iverine

n case-

-390 .

system

Jeorgia

G. and

inkton

Drysdale, R.N. (1999) The sedimentological significance of hydropsychid caddis-fly larvae (Order: Trichoptera) in a travertine-depositing stream: Louie Creek, Northwest Queensland, Australia. Journal of Sedimentary Research 69, 145-150.

Dudley, T. (1992) Beneficial effects of herbivores on stream macroalgae via epiphyte removal. Oikos $65,121-127$.

Dudley, T. and Anderson, N.H. (1982) A survey of invertebrates associated with wood debris in aquatic habitats. Melanderia 39, 1-21.

Feminella, J.W. and Hawkins, C.P. (1995) Interactions between stream herbivores and periphyton: a quantitative analysis of past experiments. Journal of the North American Benthological Society 14, 465-509.

Findlay, S., Pace, M.L. and Fischer, D.T. (1998) Response of heterotrophic planktonic bacteria to the zebra mussel invasion of the tidal freshwater Hudson River. Microbial Ecology 36, 131-140.

Fremling, C.R. (1960) Biology and possible control of nuisance caddisflies of the upper Mississippi River. Research Bulletin of the Iowa Agriculture Experiment Station 348 , 856-879.

Frissell, C.A., Liss, W.J, Warren, C.E. and Hurley, M.D. (1986) A hierarchical framework for stream habitat classification: viewing streams in a watershed context. Environmental Management 10, 199-214.

Georgian, T. and Thorp. J.H. (1992) Effects of microhabitat selection on feeding rates of net-spinning caddisfly larvae. Ecology 73, 229-240.

Golladay, S.W., Webster, J.R. and Benfield, E.F. (1983) Factors affecting food utilization by a leaf shredding aquatic insect: leaf species and conditioning time. Holarctic Ecology 6, 157-162.

Gregory, S.V. (1983) Plant-herbivore interactions in stream systems. In: Barnes, J.R. and Minshall, G.W. (eds) Stream Ecology: Application and Testing of General Ecological Theory. Plenum, New York, pp. 157-189.

Grubaugh, J.W. and Wallace, J.B. (1995) Functional structure and production of the benthic community in a Piedmont river: 1956-1957 and 1991-1992. Limnology and Oceanography 40, 490-501.

Grubaugh, J.W., Wallace, J.B. and Houston, E.S. (1997) Production of benthic macroinvertebrate communities along a southern Appalachian river continuum. Freshwater Biology 37, 581-596.

Hall, R.O., Peredney, C.L. and Meyer, J.L. (1996) The effect of invertebrate consumption on bacterial transport in a mountain stream. Limnology and Oceanography 41 , 1180-1187.

Hall, R.O., Wallace, J.B. and Eggert, S.L. (2000) Organic matter flow in stream food webs with reduced detrital resource base. Ecology (in press).

Harmon, M.E., Franklin, J.F., Swanson, F.J., Sollins, P., Gregory, S.V., Lattin, J.D., Anderson, N.H., Cline, S.P., Aumen, N.G., Sedell, J.R., Lienkaemper, G.W., Cromack, K. and Cummins, K.W. (1986) Ecology of coarse woody debris in temperate ecosystems. Advances in Ecological Research 15, 133-302. 
Hildrew, A.G. (1992) Food webs and species interactions. In: Calow, P. and Petts, G.E. (eds) The Rivers Handbook: Hydrological and Ecological Principles, Vol. 1. Blackwell, Oxford, pp. 309-330.

Hunter, M.D. and Price, P.W. (1992) Playing chutes and ladders: heterogeneity and the relative roles of bottom-up and top-down forces in natural communities. Ecology 73 , 724-732.

Huryn, A.D. (1998) Ecosystem-level evidence for top-down and bottom-up control of production in a grassland stream system. Oecologia 115, 173-183.

Huryn, A.D. and Wallace, J.B. (1987) Local geomorphology as a determinant of macrofaunal production in a mountain stream. Ecology 68, 1932-1942.

Jacobsen, D. (1993) Trichopteran larvae as consumers of submerged angiosperms in running waters. Oikos 67, 379-383.

Jacobsen, D. and Sand-Jensen, K. (1994a) Invertebrate herbivory on the submerged macrophyte Potamogeton perfoliatus in a Danish stream. Freshwater Biology 31, 43-52.

Jacobsen, D. and Sand-Jensen, K. (1994b) Growth and energetics of a trichopteran larva feeding on fresh submerged and terrestrial plants. Oecologia 97, 412-418.

Jones, J.B. (1997) Benthic organic matter storage in streams: influence of detrital import and export, retention mechanisms, and climate. Journal of the North American Benthological Society 16, 109-119.

Kohler, S.L. and Wiley, M.J. (1997) Pathogen outbreaks reveal large-scale effects of competition in stream communities. Ecology 78, 2164-2176.

Lamberti, G.A. and Moore, J.W. (1984) Aquatic insects as primary consumers. In: Resh, V.H. and Rosenberg, D.M. (eds) The Ecology of Aquatic Insects. Praeger, New York, pp. 164-195.

Lamberti, G.A. and Resh, V.H. (1983) Stream periphyton and insect herbivores: an experimental study of grazing by a caddisfly population. Ecology 64, 1124-1135.

Lamberti, G.A., Gregory, S.V., Ashkenas, L.R., Steinman, A.D. and McIntire, C.D. (1989) Productive capacity of periphyton as a determinant of plant-animal interactions in streams. Ecology 70, 1840-1856.

Lugthart, G.J. and Wallace, J.B. (1992) Effects of disturbance on benthic functional structure and production in mountain streams. Journal of the North American Benthological Society 11, 138-164.

Malmqvist, B. (1993) Interactions in stream leaf packs: effects of a stonefly predator on detritivores and organic matter processing. Oikos 66, 454-462.

McDiffett, W.E. (1970) The transformation of energy by a stream detritivore, Pteronarcys scotti (Plecoptera). Ecology 51, 975-988.

McKie, B.G.L. and Cranston, P.S. (1998) Keystone coleopterans? Colonization by woodfeeding elmids of experimentally immersed woods in south-eastern Australia. Marine and Freshwater Research 49, 79-88.

McNair, J.N., Newbold, J.D. and Hart, D.D. (1997) Turbulent transport of suspended particles and dispersing benthic organisms: how long to hit bottom? Journal of Theoretical Biology 188, 29-52.

Merritt, R.W. and Cummins, K.W. (eds) (1996) An Introduction to the Aquatic Insects of North America, 2nd edn. Kendall/Hunt, Dubuque, Iowa.

Merritt, R.W., Cummins, K.W. and Burton. T.M. (1984) The role of aquatic insects in the processing and cycling of nutrients. In: Resh, V.H. and Rosenberg, D.M. (eds) The Ecology of Aquatic Insects. Praeger, New York, pp. 134-163.

Meyer, J.L. (1990) A blackwater perspective on riverine ecosystems. BioScience 40, 643-651. 
etts, G.E. lackwell,

1 and the ology 73 ,

ontrol of

If macro-

perms in

omerged

,43-52.

an larva

Il import

merican

:ffects of

n: Resh, sw York,

ores: an $-1135$. . (1989)

stions in

Ictional

merican

lator on

ronarcys

y wood-

stralia.

pended

urnal of

1sects of

is in the

sds) The

nee 40 ,
Meyer, J.L. and O'Hop, J. (1983) Leaf-shredding insects as a source of dissolved organic carbon in headwater streams. American Midland Naturalist 109, 175-183.

Meyer, J.L., Wallace, J.B. and Eggert, S.L. (1998) Leaf litter as a source of dissolved organic carbon in streams. Ecosystems 1, 240-249.

Mihuc, T.B. (1997) The functional trophic role of lotic primary consumers: generalist versus specialist strategies. Freshwater Biology 37, 455-462.

Minshall, G.W. (1988) Stream ecosystem theory: a global perspective. Journal of the North American Benthological Society 7, 263-288.

Minshall, G.W., Petersen, R.C., Cummins, K.W., Bott, T.L., Sedell, J.R., Cushing, C.E. and Vannote, R.L. (1983) Interbiome comparison of stream ecosystem dynamics. Ecological Monographs 53, 1-25.

Morin, A., Back, C., Chalifour, A., Boisvert, J. and Peters, R.H. (1988) Effect of black fly ingestion and assimilation on seston transport in a Quebec lake outlet. Canadian Journal of Fisheries and Aquatic Sciences 45, 705-714.

Mulholland, P.J., Newbold, J.D., Elwood, J.W. and Hom, C.L. (1983) The effect of grazing intensity on phosphorus spiralling in autotrophic streams. Oecologia 58, 358-366.

Mulholland, P.J., Steinman, A.D., Palumbo, A.V. and DeAngelis, D.L. (1991) Influence of nutrients and grazing on the response of stream periphyton communities to a scour disturbance. Journal of the North American Benthological Society 10, 127-142.

Naiman, R.J. and Sedell, J.R. (1979) Characterization of particulate organic matter transported by some Cascade Mountain streams. Journal of the Fisheries Research Board of Canada 36, 17-31.

Newbold, J.D., Elwood, J.W., O'Neill, R.V. and Van Winkle, W. (1982) Nutrient spiralling in streams: implications for nutrient limitation and invertebrate activity. American Naturalist 120, 628-652.

Newman, R.M. (1991) Herbivory and detritivory on freshwater macrophytes by invertebrates: a review. Journal of the North American Benthological Society 10, 89-114.

NTSB (1989) Collapse of the S.R. 675 Bridge Spans over the Pocomoke River near Pocomoke City. Maryland. PB89-916205. National Transportation Safety Board/HAR-89/04.1-80, Washington, DC.

Oberndorfer, R.Y., McArthur, J.V. and Barnes, J.R. (1984) The effect of invertebrate predators on leaf litter processing in an alpine stream. Ecology 65, 1325-1331.

Pace, M.L., Findlay, S.E.G. and Fischer, D. (1998) Effects of an invasive bivalve on the zooplankton community of the Hudson River. Freshwater Biology 39, 103-116.

Palmer, M.A., Covich, A.P., Finlay, B.J., Gibert, J., Hyde, K.D., Johnson, R.K., Kairesalo, T., Lake, S., Lovell, C.R., Naiman, R.J., Ricci, C., Sabater, F. and Strayer, D. (1997) Biodiversity and ecosystem processes in freshwater sediments. Ambio 26, 571-577.

Parker, C.R. and Voshell, J.R. (1983) Production of filter-feeding Trichoptera in an impounded and free flowing river. Canadian Journal of Zoology 61, 70-87.

Petersen, L.B.-M. (1985) Food preferences in three species of Hydropsyche (Trichoptera). Verhandlungen der Internationalen Vereinigung für Theoretische und Angewandte Limnologie 22, 3270-3274.

Petersen, L.B.-M. (1989) Resource utilization of coexisting species of Hydropsychidae (Trichoptera). Archiv für Hydrobiologie (Suppl.) 83, 83-119.

Petersen, R.C. and Cummins, K.W. (1974) Leaf processing in a woodland stream. Freshwater Biology 4, 343-368.

Peterson, B.J., Bahr, M. and Kling, G.W. (1997) A tracer investigation of nitrogen cycling in a pristine tundra river. Canadian Journal of Fisheries and Aquatic Sciences 54. 2361-2367. 
Phelps, H.L. (1994) The Asiatic clam (Corbicula fluminea) invasion and system-level ecological change in the Potomac river estuary near Washington D.C. Estuaries 17, 614-621.

Polis, G.A. (1994) Food webs, trophic cascades and community structure. Australian Journal of Ecology 19, 121-136.

Polis, G.A. and Holt, R.D. (1992) Intraguild predation - the dynamics of complex trophic interactions. Trends in Ecology and Evolution 7, 151-154.

Polis, G.A. and Strong, D. (1996) Food web complexity and community dynamics. American Naturalist 147, 813-846.

Power, M.E. (1990) Effects of fish in river food webs. Science 250, 811-814.

Power, M.E. (1992a) Top-down and bottom-up forces in food webs: do plants have primacy? Ecology 73, 733-746.

Power, M.E. (1992b) Habitat heterogeneity and the functional significance of fish in river food webs. Ecology 73, 1675-1688.

Pringle, C.M., Naiman, R.J., Bretschko, G., Karr, J.R., Oswood, M.W., Webster, J.R., Welcomme, R.L. and Winterbourn, M.J. (1988) Patch dynamics in lotic systems: the stream as a mosaic. Journal of the North American Benthological Society 7, 503-524.

Pringle, C.M., Blake, G.A., Covich, A.P., Buzby, K.M. and Finley, A. (1993) Effects of omnivorous shrimp in a montane tropical stream: sediment removal, disturbance of sessile invertebrates and enhancement of understory algal biomass. Oecologia 93 , $1-11$.

Rosi, E.J. (1997) The trophic basis of production along a river continuum: temporal and spatial variability in the flow of energy in aquatic macroinvertebrate communities. Master's thesis, University of Georgia, USA.

Short, R.A. and Maslin, P.E. (1977) Processing of leaf litter by a stream detritivore: effect on nutrient availability to collectors. Ecology 58, 935-938.

Sih, A. and Wooster, D. (1994) Prey behavior, prey dispersal, and predator impacts on stream prey. Ecology 75, 1199-1207.

Soluk, D.A. and Craig, D.A. (1988) Vortex feeding from pits in the sand: a unique method of suspension feeding used by a stream invertebrate. Limnology and Oceanography $33,638-645$.

Soluk, D.A. and Craig, D.A. (1990) Digging with a vortex: flow manipulation facilitates prey capture by a predatory stream mayfly. Limnology and Oceanography 35, 1201-1206.

Statzner, B. and Higler, B. (1985) Questions and comments on the river continuum concept. Canadian Journal of Fisheries and Aquatic Sciences 42, 1038-1044.

Statzner, B., Fuchs, U. and Higler, L.W.G. (1996) Sand erosion by mobile predaceous stream insects: implications for ecology and hydrology. Water Resources Research 32, 2279-2287.

Steinman, A.D., Mulholland, P.J. and Beauchamp, J.J. (1995) Effects of biomass, light, and grazing on phosphorus cycling in stream periphyton communities. Journal of the North American Benthological Society 14, 371-381.

Stites, D.L., Benke, A.C. and Gillespie, D.M. (1995) Population dynamics, growth and production of the Asiatic clam, Corbicula fluminea, in a blackwater river. Canadian Journal of Fisheries and Aquatic Sciences 52, 425-437.

Thorp. J.H. and Covich. A.P. (eds) (1991) Ecology and Classification of North American Freshwater Invertebrates. Academic Press, San Diego.

Triska, FJ. and Cromack, K. (1980) The role of woody debris in forests and streams. In: Waring, R.H. (ed.) Forests: Fresh Perspectives from Ecosystem Analysis. Oregon State University Press, Corvallis, pp. 171-190. 
:em-level

laries 17 .

ustralian

$\mathrm{x}$ trophic

'namics.

nts have

$\mathrm{b}$ in river

ter, J.R., ems: the 13-524.

'ffects of urbance logia 93 ,

oral and sunities.

re: effect

sacts on

method ography

Ites prey $-1206$. tinuum laceous $\operatorname{arch} 32$,

s, light, urnal of

th and madian

nerican

ms. In: n State
Vannote, R.L., Minshall, G.W., Cummins, K.W., Sedell, J.R. and Cushing, C.E. (1980) The river continu um concept. Canadian Journal of Fisheries and Aquatic Sciences 37 , 130-137.

Voshell, J.R. (1985) Trophic Basis of Production for Macroinvertebrates in the New River below Bluestone Dam. Department of Entomology, Virginia Polytechnic Institute and State University, Blacksburg.

Wagner, R. (1991) The influence of the diel activity pattern of the larvae of Sericostoma personatum (Kirby and Spence) (Trichoptera) on organic matter distribution in stream-bed sediments - a laboratory study. Hydrobiologia 224, 65-70.

Wallace, J.B. and Merritt, R.W. (1980) Filter-feeding ecology of aquatic insects. Annual Review of Entomology 25, 103-132.

Wallace, J.B. and O'Hop, J. (1985) Life on a fast pad: water-lily leaf beetle impact on water-lilies. Ecology 66, 1534-1544.

Wallace, J.B. and Webster, J.R. (1996) The role of macroinvertebrates in stream ecosystem function. Annual Review of Entomology 41, 115-139.

Wallace, J.B., Webster, J.R. and Woodall, W.R. (1977) The role of filter-feeders in flowing waters. Archiv für Hydrobiologie 79, 506-532.

Wallace, J.B., Webster, J.R. and Cuffney, T.F. (1982) Stream detritus dynamics: regulation by invertebrate consumers. Oecologia 53, 197-200.

Wallace, J.B., Vogel, D.S. and Cuffney, T.F. (1986) Recovery of a headwater stream from an insecticide-induced community disturbance. Journal of the North American Benthological Society 5, 115-126.

Wallace, J.B., Cuffney, T.F., Webster, J.R., Lugthart, G.J., Chung, K. and Goldowitz, B.S. (1991) A five-year study of export of fine organic particles from headwater streams: effects of season, extreme discharges, and invertebrate manipulation. Limnology and Oceanography 36, 670-682.

Wallace, J.B., Whiles, M.R., Webster, J.R., Cuffney, T.F., Lugthart, G.J. and Chung, K. (1993) Dynamics of inorganic particles in headwater streams: linkages with invertebrates. Journal of the North American Benthological Society 12 , 112-125.

Wallace, J.B., Eggert, S.L., Meyer, J.L. and Webster, J.R. (1997) Multiple trophic levels of a forest stream linked to terrestrial litter inputs. Science 277, 102-104.

Wallace, J.B., Eggert, S.L., Meyer, J.L. and Webster, J.R. (1999) Effects of resource reduction on a detrital-based ecosystem. Ecological Monographs (in press).

Webster, J.R. and Meyer, J.L. (1997) Organic matter budgets for streams: a synthesis. Journal of the North American Benthological Society 16, 141-161.

Webster, J.R. and Patten, B.C. (1979) Effects of watershed perturbation on stream potassium and calcium dynamics. Ecological Monographs 49, 51-72.

Webster, J.R., Wallace, J.B. and Benfield, E.F. (1995) Organic processes in streams of the eastern United States. In: Cushing, C.E., Minshall, G.W. and Cummins, K.W. (eds) River and Stream Ecosystems. Elsevier, Amsterdam, pp. 103-164.

Welker, M. and Walz, N. (1998) Can mussels control plankton in rivers? - a planktological approach applying a Lagrangian sampling strategy. Limnology and Oceanography 43, 753-762.

Wolf, B., Zwick, P. and Marxsen, J. (1997) Feeding ecology of the freshwater detritivore Ptychoptera paludosa (Diptera, Nematocera). Freshwater Biology 38, 375-386.

Wooster, D. (1994) Predator impacts on stream benthic prey. Oecologia 99, 7-15.

Wotton, R.S. (1987) Lake outlet blackflies - the dynamics of filter feeders at very high population densities. Holarctic Ecology 10, 65-72. 
Wotton, R.S., Malmqvist, B., Muotka, T. and Larsson, K. (1998) Fecal pellets from a dense aggregation of suspension-feeders in a stream: an example of ecosystem engineering. Limnology and Oceanography 43, 719-725.

Zanetell, B.A. and Peckarsky, B.L. (1996) Stoneflies as ecological engineers - hungry predators reduce fine sediments in stream beds. Freshwater Biology 36, 569-577. 